\title{
How the Holodomor Can Be Integrated into our Understanding of Genocide
}

\author{
Norman M. Naimark \\ Stanford University
}

\begin{abstract}
The study of the Holodomor should be integrated into a broader understanding of genocide as a whole, given that a consensus that has evolved among a substantial group of scholars that the Ukrainian Famine of 1932-33 fits the general template of genocide. Raphael Lemkin, who introduced this concept into the legal structure of the international system, was clearly aware of the famine of 193233 and developed a notion of the "Soviet Genocide in the Ukraine" as a multipronged genocidal assault on the Ukrainian people. The events of the Holodomor remained largely unknown to the general Western public until the publication of Robert Conquest's Harvest of Sorrow in 1986. Presently, the links between the study of the Holodomor and genocide studies in North America are relatively underdeveloped. As such, there are many aspects of genocide studies that could be illuminated by an understanding of the Holodomor. These include its examination as a "Communist genocide" as per Mao's 1950s famine or Cambodia, but perhaps more specifically within the context of Stalin's actions in the 1930s. Another important aspect is the problem of isolating ethnic from social and political categories: the Holodomor saw a concomitant attack on the Ukrainian intelligentsia and Ukrainian language and culture. The question of the numbers of victims remains controversial, although the figure of 3-5 million Ukrainians who died in Ukraine and the Kuban seems to withstand scrutiny. Finally, there is the question of intentionality. Here, in light of recent interpretations of international law, it seems quite clear that Stalin was responsible for genocide in the case of the Holodomor.
\end{abstract}

Keywords: Famine, Genocide, Holodomor, Raphael Lemkin

$\mathbf{T}$ he study of the Holodomor can and should be integrated into a broader understanding of genocide as a whole. Until recently, arguments among scholars regarding the Ukrainian killer-famine of 1932-33 have focused on whether the Holodomor should be considered a case of genocide or not. While it would be premature to conclude that these arguments have been fully resolved, it is nevertheless the case that a consensus has evolved among a substantial group of scholars that the Holodomor fits the general template of genocide. ${ }^{1}$ Once one agrees that the Holodomor should be

1 The editors of a recent study of the consequences of the Holodomor note also that there is a growing consensus on the number of victims and on the background and 
considered genocide, the issue of how to think about it in the context of the history of genocide as a persistent historical phenomenon becomes particularly salient. How does the Holodomor help us comprehend genocide better and how does examining the Holodomor as genocide help us comes to terms in more nuanced ways with the events of 1932-33? The assumption of this essay is that comparing the Holodomor with other episodes of genocide in the modern world and integrating it fully with what we would call "genocide studies" helps illuminate its causes, course, and consequences, as well as the nature of genocide itself.

RAPHAEL LEMKIN AND THE UKRAINIAN FAMINE OF 1932-33

The appropriate place to begin a consideration of the Holodomor in the context of genocide studies is with the towering figure of Raphael Lemkin, the intriguing and controversial Polish-Jewish lawyer who coined the term genocide, gave it substantial meaning, and helped introduce it into the language and legal structure of the international system. Lemkin was also the founding father of genocide studies, as he researched and drafted large parts of a world history of genocide in the late 1940s and early 1950s. In fact, his contributions to understanding the phenomenon of genocide integrate legal thinking with history and social science in a manner that continues to inspire scholars and students. For our understanding of the Holodomor in the context of genocide, it is important to add that his career also intersected with the history of Ukraine and the Ukrainian famine, about which he wrote and spoke (Serbyn).

Raphael Lemkin was born in the Białystok region of Poland (then part of the Russian Empire) in 1900.2 Already in the 1920s in the Polish Second Republic, he was fascinated by such horrific episodes in history as the massacres of the Albigensians in the thirteenth century and the destruction of the Armenians in 1915. Before practicing law in Warsaw, he studied in Lviv, where he surely must have become aware of Ukrainian issues, though to date there is little information on his activities there. In 1933, prompted by the Simele massacre of Assyrian Christians in northern Iraq, Lemkin authored a legal brief sponsored by international lawyers presented to a League of Nations meeting in Madrid that condemned what he called the

consequences of the famine. See Graziosi, Hajda, and Hryn xvi.

2 Much of the biographical information on Lemkin comes from the most comprehensive scholarly study of his life and work by John Cooper (Cooper) and Samantha Power's groundbreaking book (Powers). See also my discussion of Lemkin (Naimark 15-29). 
crime of "barbarism." His proposal stated: "Whosoever, out of hatred towards a racial religious or social collectivity, or with a view of the extermination thereof, undertakes a punishable action against the life, bodily integrity, liberty, dignity or economic existence of a person belonging to that collectivity, is liable for the crime of barbarity." Lemkin also introduced to the assembly the concept of "vandalism," the core of which was cultural genocide, the destruction of memorials, churches, language use, and other cultural attributes of groups of people (cited in Power 521, note 6). There are three important aspects of Lemkin's initiatives that need to be emphasized in order to understand the arguments to come: 1) Lemkin identified what was essentially the crime of genocide before the coming of the Holocaust; 2) He included social collectivities into his analysis, perhaps in response to the beginning of Soviet attacks on nationalities; and 3) He understood the linkages between mass killing ("barbarism") and cultural genocide ("vandalism").

Lemkin made little headway with the League of Nations, but, with the rise of Nazism in Germany, he became all the more convinced that international law was the only means to insure the rights of groups of potential victims of mass killing. When the Third Reich invaded Poland in September 1939, he found his way out of the country to Sweden and then to the United States, where he taught law at Duke University in 1941. Supported by the Carnegie Endowment for International Peace and serving as a consultant to the War Department in Washington D.C., Lemkin collected materials on the Axis occupation of Europe, which documented the discrimination against religious and ethnic groups that had become an integral part of Hitler's Europe. In the process, he came up with the term "genocide," which he defined in his 1944 book, Axis Rule in Occupied Europe: "The practices of extermination of nations and ethnic groups as carried out by the invaders [the Nazis and their allies] is called by the author 'genocide,' a term deriving from the Greek word genos and the Latin cide (by way of analogy, see homicide, fratricide)" (Lemkin 79). Clearly, Lemkin had found a term that created sparks as it rubbed up against the growing consciousness of the Western public as it eventually confronted the Holocaust and other monstrous crimes of mass killing. Although it was initially hard to arouse much interest in the fate of the Jews during or after the war, Lemkin's experiences with the Nazis and his justifiable fears about what had happened to his family in Poland served to focus much of his efforts on publicizing the desperate plight of the Jews.

An amazingly tireless lobbyist, Lemkin was at Nuremberg in the late fall of 1946, trying to convince the prosecutors to include genocide in the indictment against Nazis standing trial for war crimes. But the international court was much more interested in the condemnation of aggressive war 
than in the mass murder of the Jews or anyone else. Lemkin then worked the corridors of the United Nations to promote the passage of an international law against genocide. Here he had more success, as the Soviets, Poles, Yugoslavs, and other victims of Hitler's crimes joined forces with Jewish groups to encourage the General Assembly to pass a resolution of December 1946 condemning the crime of genocide "whether it is committed on religious, racial, political, or any other grounds [my emphasis]" and charge the U.N. Sixth (Legal) Committee to draft a convention against genocide (Robinson 17-18; see Resolution 96 (I) in appendix 1, 121-22). In the process of the deliberations about the convention, the Soviets and their Allies (and other countries) insisted that social and political groups be dropped completely from the language of the document, which is crucial for thinking about the Holodomor as genocide. Thus, the Convention on the Prevention and Punishment of Genocide, unanimously adopted by the General Assembly of the United Nations on 9 December 1948, with Lemkin in the gallery, famously defined genocide as a variety of "acts committed with the intent to destroy, in whole or in part a national, ethnical, racial or religious group, as such." Although the convention explicitly recognized, in the spirit of Lemkin, that genocide "has inflicted great losses on humanity... at all periods of history," its language and spirit were understandably entwined with the immediate past of world war and the piles of corpses left behind by the Nazis ("The Convention on the Prevention and Punishment of the Crime of Genocide" 38).

Lemkin himself had a fairly clear-headed idea of what the Ukrainian killer famine of 1932-33 entailed. He was well aware of the travails of the Ukrainians under Soviet, as well as Nazi rule. He had been deeply suspicious of Soviet power as it spread into Eastern Europe and his native Poland after the Second World War. While in New York, he developed good ties with the exile communities of the so-called "captive nations" - Lithuanians, Latvians, and Ukrainians, among others. In a 1953 speech, called "Soviet Genocide in the Ukraine," Lemkin described the attempted destruction of the Ukrainian nation in four stages: first, the attacks on the Ukrainian intelligentsia, when "teachers, artists, thinkers, political leaders were liquidated, imprisoned, deported"; second, the attack on the Ukrainian churches, priests, and hierarchy, which included the execution of thousands of priests; third, the assault on the villages through an artificial famine-in Lemkin's words "a famine to order, by plan," through excess grain requisitioning; and last, and essential to the entire process, the diminishing and dispersal of the Ukrainian population, while bringing Russians and other nationalities into Ukraine (Serbyn 123-30).

Although Lemkin's instincts about the Holodomor in the 1953 speech were on the mark, he couched his analysis in extreme anti-Soviet and anti- 
Communist rhetoric. This fit well with the tenor of Joseph McCarthy's paranoid crusade against Communists in American life, but, at the same, it isolated him from the mainstream of the community of international lawyers. He also displayed in some of his writing an exaggerated Russophobia, though that, too, fit the tenor of the times. The language he used ultimately tended to undermine his attempts to lobby more effectively on behalf of the captive nations. For example, in the speech on "Soviet Genocide in Ukraine," quoted above, he considered the killer famine in the same continuous sequence of historical events as Catherine the Great's persecution of the Crimean Tatars, the mass murders of what he called the "SS troops" of Ivan "the Terrible," the oprichnina, the tsarist pogroms against Russian Jews, and "the extermination of National Polish leaders and Ukrainian Catholics by Nicholas I" (Serbyn 123-30). None of these events can be thought of as genocide; none constituted mass killing of the sort represented by the Holodomor. Nevertheless, Lemkin is a real hero of the genocide story, and it is certainly an admirable part of his lasting legacy that he understood the genocidal essence of the 1932-33 killer famine in Ukraine.

Despite Lemkin's best efforts, the Genocide Convention had almost no serious resonance in international affairs until the 1990s, long after his death in relative obscurity in August 1959. The United States Senate would not even ratify the convention until 1986, and the Congress did not accept it into law until 1988. There was also the issue that for nearly forty years after the convention, the definition of genocide and its understanding in Western society was almost exclusively linked to the Holocaust and the fate of the Jews during World War II. It took some time and some effort before scholars and political activists were able to apply the term without opprobrium to other historical cases, like the Armenian massacres of 1915, the Ukrainian famine of 1932-33, or the elimination of some American Indian tribes. ${ }^{3}$

By the middle of the 1990s, specially appointed international courts began to apply the 1948 Genocide Convention to the crimes of mass murder carried out in Bosnia, Rwanda, Sierra Leone, and eventually Darfur and Cambodia. In international jurisprudence, there was no longer any concern that indicting Serb mass murderers like General Ratko Mladić, and Radovan Karadžić, or convicting the Hutu General Theoneste Bagosora of genocide (and sentencing him to life in prison) diminished in any way the Holocaust. In fact, the international judges and lawyers sometimes referred in their

\footnotetext{
${ }^{3}$ For definitional problems of genocide, see, among others, Levene 35-89 and WeissWendt 42-70.
} 
statements and judgments to the precedents of Nuremberg and to the origins of the Genocide Convention. At the same time, since the mid-1990s the work of the courts - the indictments, the arguments, the witness testimonies, the sentencing-have added measurably to the sophistication of scholarship about genocide, demonstrating again the validity of Lemkin's approach of combining international legal scholarship with historical case studies. ${ }^{4}$ Scholars, too, have published increasingly detailed studies about diverse prototypes of genocide that have opened up Lemkin's concept to many previously marginalized cases, including the Holodomor. ${ }^{5}$ Perhaps most importantly, genocide has become part of a larger public discourse about international politics; Bosnia, Rwanda, Darfur, and other cases of genocidal mass killing have made front-page news, as Western governments considered whether to intervene, as they are at the moment in Syria. Indicative in some ways of the attention to the issue of genocide is the appointment of Samantha Power as United States Ambassador to the United Nations. Power was one of the first to write comprehensively about genocide and the contributions of Raphael Lemkin.

Although the events of the Holodomor were well known within the Ukrainian community in the United States and Canada almost from the time the horrific starvation was taking place, it took Robert Conquest's much praised-but also earlier much maligned-book, Harvest of Sorrow, published in 1986, a relatively late date, to bring the Holodomor the attention of the broader public (Conquest). (To put this into context, Raul Hilberg had an extremely difficult time trying to publish his foundational The Destruction of the European Jews published. It came out only in 1961 in English and 1982 in German! [Hilberg]) It is also worth recalling that scholars frequently criticized Conquest's analysis as storytelling based on unreliable personal memoirs rather than empirically verifiable history. It really took the fall of the Soviet Union and the opening of some Ukrainian and Russian archival collections to domestic and foreign scholars to provide the kinds of data about the Ukrainian countryside and insights into the workings of Stalin's Kremlin that would be convincing to skeptics in and outside of academia.

\footnotetext{
4 The most successful and useful application of Lemkin's approach is no doubt the international legal scholar, William A. Schabas (cf. Schabas).

5 The most prominent textbooks on genocide include the Holodomor in their considerations: Totten and Parsons (includes a chapter by James Mace); Jones (includes the Holodomor as part of a consideration of Stalin's crimes); Chalk and Jonassohn (includes an excerpt from Harvest of Sorrow); and Kiernan.
} 


\section{THE HOLODOMOR AND GENOCIDE STUDIES}

At this writing, it is fair to say that the study of the Holodomor is developing very rapidly both in Ukraine and North America and that genocide studies is growing by leaps and bounds. But the links between the two areas of knowledge production are relatively underdeveloped. What follows, then, is an attempt to bridge that gap and to demonstrate that there are many aspects of the study of genocide that are illuminated by an understanding of the Holodomor. At the same time, the Holodomor fits well into the general taxonomy of genocide. It is not an unusual or outlier case, and therefore much can be learned from it. The points enumerated here, it should be clear, are intended as exploratory categories for comparison. These are not meant to be either exhaustive or complete, but rather as starting points for further discussion.

1. Perhaps the most obvious thing to say about the Holodomor is that it is a case of what can be classified as Communist genocide. Communist genocides took place in the Soviet Union in the 1930s, in Maoist China during the Great Leap Forward at the end of the 1950s, and in Cambodia, during the horror years of Khmer Rouge rule, from 1965 to the beginning of 1969. Communism as an ideology in power was susceptible to the transformative millenarianism of charismatic leaders like Stalin, Mao, and Pol Pot. One can read in Marx and especially in Lenin justifications for the elimination of large groups of people for the higher purposes divined by the Communist Party. ${ }^{6}$ Violence, in Marx's famous words (according to Engels) is "the midwife of every old society pregnant with a new one" (cited in Fromm 21 from Das Kapital, vol. I). But it takes particular kinds of leaders with nearly unlimited power and a complete disdain for human life to engage in the kinds of programs that could take millions of lives without the least hesitancy. This also relates to the disdain of Communist societies for the peasantry. For Mao and Stalin, in particular, the peasants were treated as transitional material. Some would argue that Lenin falls into this category of murderers, as well. But the differences between Lenin's attitudes towards killing and Stalin's were marked. Lenin's included some rational relationship between means and ends; Stalin's, by most accounts, did not.

2. More specifically, the Holodomor is a case of what might be called "Stalin's genocides" (Naimark 70-79). The Ukrainian killer-famine of 193233 fully conformed to the ways in which Stalin constructed a whole series of

\footnotetext{
6 On Lenin, see Pipes 1-11. Pipes notes here that Lenin had an "utter disregard for human life." See as well, Gellately 53-57.
} 
attacks on alleged enemies of the Soviet Union in the course of the 1930s. There was the murderous de-kulakization campaign in the early 1930s, the attack on nationalities, which stretched from the early 1930s through the war, the elimination of "asocial" groups in Order 00447, and the assault on alleged political conspiracies in 1937-38. Because of their opposition to collectivization and grain requisitioning, the Ukrainian peasants were identified as kulaks (kurkuls in Ukrainian), Petliurites, and counterrevolutionaries. Too often in the literature, these events are considered in isolation from one another. Stalin harbored images of a fantastic plot in which the grain delivery crisis, induced by his government's own policies of collectivization, would prompt Polish agents and Ukrainian nationalists to pry the republic loose from the union. "We may lose Ukraine," Stalin ominously wrote to Kaganovich in August 1932.7 In 1930, just as during the Civil War, there were widespread Ukrainian peasant uprisings that could lead to separatist movements. A growing and increasingly sophisticated literature on Stalin emphasizes the role of war scares in the genocidal programs of transformation that he initiated in the 1930s (Khlevniuk 148). In my view-and a study of the Holodomor backs this up - these fantastic plots were fictions that were superimposed on murderous policies of mass killing.

3. The Holodomor was a case of mass killing by starvation. Like Mao's Great Leap Forward, during which, according to Frank Dikötter, 45 million people died, and Pol Pot's purposeful use of food deprivation to kill alleged opponents from the "new people," as urbanites, teachers, and other professionals were called by the Khmer Rouge, the Holodomor was brought on by a dictator and his retinue, not by natural causes (Dikötter $\mathrm{x}$ ). The same could be said of Hitler's execution by starvation of nearly three million Soviet POWs in the first years after his invasion of the Soviet Union. Amartya Sen puts the issue of killer famines succinctly when he writes: “... starvation is a matter of some people not having enough food to eat and not a matter of there being not enough food to eat. While the latter can be a cause of the former, it is clearly one of many possible influences" (Sen 434). We know that in the case of Stalin's Soviet Union, Mao's China, Pol Pot's Cambodia, and Hitler's Germany, there was indeed enough to eat. The cause of death by starvation was purposeful food deprivation. In short, Stalin and the Soviet and Ukrainian Communists with whom he worked took the food out of the Ukrainian peasantry's mouths; they starved; and they were accorded no succor or relief. They were not allowed to seek food outside

${ }^{7}$ Cited in Kuromiya 111-12. An excerpt of the August 11, 1932 letter is reprinted in Klid and Motyl 239-40. 
Ukraine. Burdened by a newly introduced passport system, they were not allowed after a certain point to travel to cities to find something to eat. Stalin would not admit that there was famine and he forbade foreign relief. All of these aspects of the Ukraine's killer famine were, by the by, also characteristic of the Great Leap Forward and Pol Pot's regime.

4. The insights of three memoirs on genocidal starvation, two recently published, one a classic on the Ukrainian famine, help the reader to understand better the ghastly processes involved. One is a diary by Dawid Sierakowiak, who died in the Łódź ghetto of disease associated with hunger (Sierakowiak). The second is a memoir by Loung Ung, who managed to survive the Cambodian catastrophe, though losing many of her family members, before coming to the United States (Ung). And the third is the memoir of Miron Dolot, Execution by Hunger, which was published in 1985. Dolot is a pseudonym for a Ukrainian postwar émigré to the United States, who draws a terrifying picture of rural death in the Cherkasy region of Ukraine in 1932-33. All three accounts have a haunting similarity to them: how people cope with and suffer when confronted with the purposeful deprivation of food; the search for substitutes, which sometimes poison and kill them; the changing body shapes, described as "hour glasses" by Sierokowiak; the same diseases, typhus, dysentery, diarrhea, and edema, which see bodies swell up and ooze liquids. ${ }^{8}$ There is the debilitating weakness and subsequent listlessness and the severe challenges to family and morality. I have to say of all the accounts of death in genocide that I have read, death by starvation may be the most painful and heartrending. They are also interchangeable. Accounts of death by hunger, whether in Hitler's ghettos or Stalin's Ukrainian countryside have a numbing similarity to them. The reports of people going mad with hunger, engaging in cannibalism and necrophagy, are common to genocidal famine situations. ${ }^{9}$ Citing the studies of Pitirim Sorokin, Sergei Maksudov writes: “... starvation leads some people to deteriorate, decline, and submit, while other people experience different changes-psychological and emotional; for example, callousness or, even worse, brutality. Prolonged starvation leads to changes in the traditional standards of behavior, and conditioned reflexes of social

\footnotetext{
8 Sierakowiak 47. Dolot writes, like the others, on the edema: "The bodies of others were swollen, a final stage of starvation. Their faces, arms, legs and stomachs resembled the surfaces of plastic balloons. The tissues would soon crack and burst, resulting in the fast deterioration of their bodies" (Dolot 204-205).

${ }^{9}$ First hand accounts of cannibalism and necrophagy in the Ukrainian famine were available very early on in the two-volume collection: The Black Deeds of the Kremlin: $A$ White Book (Pidhainyi). Thanks to Frank Sysyn for alerting me to the existence of these memoirs.
} 
relations cease functioning.... Starvation begins to define a person's every action, weakening or suppressing the sense of self-preservation and love for one's children and other family members.... Group self-defense weakens and friendly relations disappear; egoism increases; and all sense of humanity disappears" (Maksudov 134). Because governments actively and forcibly deny the victims' desire to seek relief, all hope is lost. The utter indifference of Stalin, Mao, Pol Pot-of Hitler, Talaat Pasha or the colonial genocidaires of indigenous peoples-to this misery is worth registering and seeking to understand.

5. The Holodomor highlights an important problem-even fallacy-in thinking about genocide in exclusively ethnic and national terms, as stipulated in the December 1948 U.N. Convention on the Prevention and Punishment of the Crime of Genocide, the founding document of contemporary jurisprudence-national and international-about genocide. First of all, thinking in terms of ethnic and national identity is often as elusive as identifying class and political groups. One can certainly exaggerate the "constructed" nature of ethnicity or nationality. Still, lines of group identity are always porous and, in genocidal situations, it is more often than not the perpetrators who attribute a particular identity, whether ethnic or national on the one hand or social and political on the other, to the victims, not the victims themselves. Secondly, many genocides (the Holodomor is only one) have mixed ethnic and class (and/or political) dimensions. And third, there are good reasons to assert that ethnic criteria should not be the sole measure of genocide. Three examples widely separated in time and space will have to suffice to illustrate these points. In the 1980s, the Guatemalan military attacked Mayan highlanders as alleged Communists and as Indians, who were also considered lesser human beings in part because of their lower class status. ${ }^{10}$ In short, the perpetrators identified the victims as a mixed social, political, and ethnic group, where one characteristic was almost always assumed by the perpetrators to include the others. A supposed army counterinsurgency against Communist guerillas was simultaneously a murderous attack on impoverished ethnic "others." A second example involves Hitler's T-4 euthanasia program, which killed some 200,000 mentally and physically handicapped Germans, a good number of them children, before the "action" was stopped by protests from German relatives and Nazi supporters against the practice (Friedlander). Should not the targeted elimination of a group of one's own people also be considered genocide? The third example has to do with what we commonly refer to as the "Cambodian Genocide." How could it be that in July 2010, the

10 On Guatemala, see, among others: Jones 377-411; Schirmer; Sanford. 
Cambodian prison camp commander and murderer and torturer of as many as 16,000 of his compatriots, Kaing Guek Eav, known as "Duch," was acquitted of all counts of genocide and received a reduced sentence reduced to 16 years for lesser "crimes against humanity" and "war crimes" because he "only" killed Cambodian urban intellectuals?"11 If he had killed Vietnamese and Cham, as some Khmer Rouge did in very large numbers, though nowhere near the numbers of Cambodians killed, then he could have been convicted of genocide.

The Holodomor and the starvation of the Ukrainian peasantry are also illustrative of the complexity of isolating ethnic from social and political categories. On one level, the Holodomor was an attack on the Ukrainian people (Mace 1-14). It was carried out in the larger context of an attack on the Ukrainian intelligentsia and Ukrainian language and culture. Yet the abandoning of the Ukrainization (indigenization) campaign-the development of Ukrainian national culture and politics fostered by Moscow in the 1920s-went hand in hand with the attack on Ukrainian peasants in the Holodomor. It was above all the stalwart Ukrainian peasantry that stuck in the craw of the Stalinist leadership, not Ukrainians who lived in Moscow or Siberia, or those who resided in the cities or factory settlements of the Ukrainian Republic. At the same time, the arguments for seeing the Holodomor as an attack primarily on Ukrainian peasantry, a mixed social and ethnic category, should not reduce the case for genocide in the least. The Holodomor resulted from a perfect storm of Stalinist national and peasant policies-which also saw the Ukrainian intellectuals, cultural leaders, and Party members attacked and eliminated. Many thousands were killed or exiled in 1933-34. In 1938 alone, there were 185,000 Ukrainian leaders arrested, the vast majority of whom were shot. An additional 244,000 were deported to the Gulag and special settlements. Stanislav Kul'chyts'kyi writes “...Ukraine was at the epicenter of Stalinist repressions” (Kul'chyts'kyi 9).

6. The question of the number of people who died as a consequence of the Holodomor remains controversial, as numbers of victims are in almost every case of genocide, though the range in the case of the Holodomor has narrowed somewhat with access to the archives. In Stalin's Genocides, I used the number of 3-5 million Ukrainians who died in Ukraine and the Kuban, though there are those who still believe the number is higher and those who think it is lower. Scholars and publicists who seek recognition of a particular genocide from a skeptical audience tend to use higher numbers.

11 After a series of appeals by both the prosecution and defense, in February 2012 Duch's sentence was increased to life in prison. 
Partisans of the victims also tend to inflate numbers, as do those who use genocide as a means to foster national identity. But there are also tendencies in genocide studies that lead to undercounting the number of victims as a way to avoid controversy. This is particularly true of the Armenian genocide, where some Ottomanists will use lower numbers and avoid the word "genocide" altogether in order not to offend the Turkish government or their fellow colleagues. ${ }^{12}$ In the case of the Ukrainian famine, and the Soviet Union, one has to be especially wary of numbers that are produced by the state and by the NKVD. Alexander Yakovlev, who was the first to work systematically in Soviet archives about the repressions of the 1930s, stated flat out that the NKVD systematically underestimated the number of dead (234). Working with census data strikes me as equally problematic. Why should one believe these data any more than one believes Soviet production figures? In Stalinist Russia, numbers were there to be manipulated. At the same time, there is a tendency among scholars who wish to appear unbiased and fair-minded to underestimate the number of victims. If one looks at the use of numbers in Timothy Snyder's estimable Bloodlands, almost all of them tend to reflect the lowest estimates (see the appendix "Numbers and Terms" 409-414). Like his unwillingness to use the word genocide to describe the Ukrainian famine or other cases of Soviet mass killing, his use of low numbers - though, of course, high enoughstrikes me as equally untenable as using inflated estimates. For the Ukrainian famine, for example, he asserts that "3.3 million Soviet citizens (mostly Ukrainians) [were] deliberately starved by their own government in Soviet Ukraine in 1932-33" (411). The number could easily have been much higher. We cannot be sure.

7. Crucial to genocide as a whole, and to analyzing the Holodomor as a case of genocide, is the question of "intent." Here, the international courts, in particular, have helped our understanding of how one should think about intent. First of all, the issue of motivation is not important in assessing intent. We do not need to know why a perpetrator did what he or she did for a genocide indictment, though, of course, the historian is always interested in such questions. We need to know if the perpetrator intended to kill a particular group of victims. One of the constant objections to the argument that the Holodomor was genocide is that it cannot be convincingly demonstrated that Stalin intended to kill the Ukrainian peasants in the famine. There was famine everywhere, the argument goes, and that the Ukrainians were hit as hard as they were resulted from their heavy dependence on agriculture. Nevertheless, there is a growing body of

12 On the dynamics of denial in the Armenian Genocide, see Suny 23-37. 
evidence indicating that Stalin indeed intended for Ukrainian peasants in the countryside to die. Most of this evidence is anecdotal, to be sure, buttaken altogether-it is convincing about Stalin's intent. Equally important is the way international law has dealt with the question of intent. In two cases having to do with genocide in Srebrenica-Radislav Kristić and Goran Jelisić-and in Jean-Paul Akayesu in connection with Rwanda, the courts determined that genocide can be considered to have taken place even if one cannot establish the chain of command to the very top. ${ }^{13}$ This was reaffirmed in the appeals, as well as before the International Criminal Court, when Bosnia sued the state of Serbia for genocide. This makes sense historically, as well, when dealing with the Holodomor. Stalin was unquestionably in charge of Soviet policy in Ukraine in 1932-33. His deputies implemented that policy. Even if we do not have the kind of systematic evidence as historians that would convince our readers that he ordered the killing of Ukrainians in the countryside by intensifying the harsh conditions of the famine, the events themselves and the context in which they unfolded indicate that he did indeed do so. As a result, Stalin was responsible for genocide in the case of the Holodomor, the Ukrainian killer famine.

\section{Works Cited}

Akayesu (ICTR-96-4-T). Web. 22 May 2014. <http://www.unictr.org/Portals/0/ Case/English/Akayesu/judgement/akay001.pdf>

Chalk, Frank R., and Kurt Jonassohn. The History and Sociology of Genocide: Analyses and Case Studies. New Haven: Yale University Press, 1990. Print.

Conquest, Robert. Harvest of Sorrow: Soviet Collectivization and the Terror-Famine. New York: Oxford University Press, 1986. Print.

"The Convention on the Prevention and Punishment of the Crime of Genocide." Totally Unofficial: Raphael Lemkin and the Genocide Convention. Ed. Adam Strom, et al. Brookline MA: Facing History and Ourselves, 2007. Print.

Cooper, John. Raphael Lemkin and the Struggle for the Genocide Convention. New York: Palgrave Macmillan, 2008. Print.

Dikötter, Frank. Mao's Great Famine: The History of China's Most Devastating Catastrophe 1958-1962. New York: Walker and Co., 2010. Print.

Dolot, Miron. Execution by Hunger: The Hidden Holocaust. New York: W. W. Norton, 1985. Print.

Friedlander, Henry. The Origins of Nazi Genocide: From Euthanasia to the Final Solution. Chapel Hill: University of North Carolina Press, 1995. Print.

13 The indictments and judgments can be found online (<www.icty.org $>$ ) under: Krstić (IT-98-33) "Srebrenica-Drina Corps"; Jelisić (IT-95-10) "Brčko"; and Akayesu (ICTR-96-4-T). 
Fromm, Erich. Marx's Concept of Man. London: Continuum, 2004. Print.

Gellately, Robert. Lenin, Stalin, and Hitler: The Age of Social Catastrophe. New York: Knopf, 2007. Print.

Graziosi, Andrea, Lubomyr A. Hajda, and Halyna Hryn, eds. After the Holodomor: The Enduring Impact of the Great Famine on Ukraine. Cambridge, MA: Harvard Papers in Ukrainian Studies, 2013. Print.

Jelisić (IT-95-10) "Brčko." Web. 22 May 2014. <http://www.icty.org/case/jelisic/4>. Hilberg, Raul. The Politics of Memory: The Journey of a Holocaust Historian. Chicago: Ivan R. Dee, 1996. Print.

Jones, Adam. Genocide: A Comprehensive Introduction. $2^{\text {nd }}$ edition. London and New York: Routledge, 2011. Print.

Jones, Susanna. "Guatemala: Genocide and Scorched Earth Counterinsurgency War." Century of Genocide. Ed. Samuel Totten and William Parsons. New York: Routledge, 2009. 377-411. Print.

Khlevniuk, Oleg. The History of the Gulag: From Collectivization to the Great Terror. Trans. Vadim A. Staklo. New Haven: Yale University Press 2004. Print.

Kiernan, Ben. Blood and Soil: A World History of Genocide and Extermination from Sparta to Darfur. New Haven: Yale University Press, 2007. Print.

Klid, Bohdan, and Alexander J. Motyl, eds. The Holodomor Reader: A Sourcebook on the Famine of 1932-1933 in Ukraine. Edmonton: Canadian Institute of Ukrainian Studies Press, 2012. Print.

Krstić (IT-98-33) "Srebrenica-Drina Corps." Web. 22 May 2014. <http:// www.icty.org/case/krstic/4>

Kul'chyts'kyi, Stanislav. "The Holodomor and Its Consequences in the Ukrainian Countryside." After the Holodomor: The Enduring Impact of the Great Famine on Ukraine. Ed. Graziosi, Andrea, Lubomyr A. Hajda, and Halyna Hryn. Cambridge, MA: Harvard Papers in Ukrainian Studies, 2013. 1-13. Print.

Kuromiya, Hiroaki. Stalin. Harlow: Longman, 2005. Print.

Lemkin, Raphael. Axis Rule in Occupied Europe: Laws of Occupation, Analysis of Government Proposals for Redress. Washington D.C.: Carnegie Endowment for International Peace, 1944. Print.

Levene, Marc. Genocide in the Age of the Nation State. Vol. I "The Meaning of Genocide." London: I. B. Tauris, 2008. Print.

Mace, James. "The Man-Made Famine of 1933 in Soviet Ukraine." Famine in Ukraine, 1932-1933. Ed. Roman Serbyn and Bohdan Krawchenko. Edmonton: Canadian Institute of Ukrainian Studies, 1986. 1-14. Print.

Maksudov, Sergei. "Dehumanization: The Change in the Moral and Ethical Consciousness of Soviet Citizens as a Result of Collectivization and Famine." After the Holodomor: The Enduring Impact of the Great Famine on Ukraine. Ed. Andrea Graziosi, Lubomyr A. Hajda, and Halyna Hryn. Cambridge, MA: Harvard Papers in Ukrainian Studies, 2013. 123-48. Print.

Naimark, Norman M. Stalin's Genocides. Princeton: Princeton University Press, 2010. Print.

Pidhainyi, Semen. The Black Deeds of the Kremlin: A White Book. Vol. I. Toronto: Ukrainian Association of Victims of Russian Communist Terror, 1953; Vol II. Detroit: Democratic Organization of Ukrainians Formerly Persecuted by the Soviet Regime in U.S.A., 1955. Print. 
Pipes, Richard, ed. The Unknown Lenin: From the Secret Archive. New Haven: Yale University Press, 1996. Print.

Power, Samantha. "A Problem from Hell": America and the Age of Genocide. New York: Basic Books, 2002. Print.

Robinson, Nehemiah. The Genocide Convention: A Commentary. New York: Institute of Jewish Affairs, 1960. Print.

Sanford, Victoria. Buried Secrets: Truth and Human Rights in Guatemala. New York: Palgrave Macmillan, 2003. Print.

Schabas, William A. Genocide in International Law: The Crime of Crimes. Cambridge, England: Cambridge University Press, 2000. Print.

Schirmer, Jennifer. The Guatemalan Military Project: A Violence Called Democracy. Philadelphia: Univ. of Pennsylvania Press, 1998. Print.

Sen, Amartya, "Ingredients of Famine Analysis: Availability and Entitlement." The Quarterly Journal of Economics 96. 3 (August 1981): 433-64. Print.

Serbyn, Roman, ed. "Lemkin on Genocide of Nations." Journal of International Criminal Justice 7 (2009): 123-30. Print.

Snyder, Timothy. Bloodlands: Europe Between Hitler and Stalin. New York: Basic Books, 2010. Print.

Suny, Ronald Grigor. "'Writing Genocide: The Fate of the Ottoman Armenians." $A$ Question of Genocide: Armenians and Turks at the End of the Ottoman Empire. Ed. Ronald Grigor Suny, Fatma Müge Gocek, and Norman M. Naimark. New York: Oxford University Press, 2011. 23-37. Print.

Sierakowiak, Dawid, Alan Adelson, and Kamil Turowski. The Diary of Dawid Sierakowiak: Five Notebooks from the Łódź Ghetto. New York: Oxford University Press, 1996. Print.

Totten, Samuel, and William S. Parsons, eds. Century of Genocide: Critical Essays and Eyewitness Accounts. New York: Routledge, 2009. Print.

Ung, Loung. First They Killed My Father: A Daughter of Cambodia Remembers. New York: HarperCollins, 2000. Print.

Weiss-Wendt, Anton. "Problems in Comparative Genocide Scholarship." The Historiography of Genocide. Ed. by Dan Stone. London: Palgrave Macmillan, 2008. 42-70. Print.

Yakovlev, Alexander N. A Century of Violence in Soviet Russia. Trans. Anthony Austen. New Haven: Yale University Press, 2002. Print. 
(C) 2015 East/West: Journal of Ukrainian Studies (ewjus.com) Volume II, No. 1 (2015) 